\title{
Katznelson's Working Within the System Now
}

\section{Citation}

Cohen, Lizabeth. 1994. Katznelson's working within the system now. International Labor and Working-Class History 46: 33-36.

\section{Published Version}

doi:10.1017/S0147547900010796

\section{Permanent link}

http://nrs.harvard.edu/urn-3:HUL.InstRepos:4699750

\section{Terms of Use}

This article was downloaded from Harvard University's DASH repository, and is made available under the terms and conditions applicable to Other Posted Material, as set forth at http:// nrs.harvard.edu/urn-3:HUL.InstRepos:dash.current.terms-of-use\#LAA

\section{Share Your Story}

The Harvard community has made this article openly available.

Please share how this access benefits you. Submit a story.

Accessibility 


\title{
Katznelson's Working Within the System Now
}

\author{
Lizabeth Cohen \\ New York University
}

Germany has been reunified. The Soviet Union and Eastern Europe have fractured into ethnically defined nationalist republics trying to dismantle decades of communist political and economic structures and replace them with free markets and free marketplaces of ideas. It seems only fitting that Ira Katznelson should publically embrace liberal political theory with a new "zest for political engagement," enthusiastically endorsing the old liberal vision of political science as a discipline, and thrusting both onto labor historians as the perfect solution to political and epistemological crises in their field. In response, I would say to Katznelson, "You're working within the system now, but do we all need to?" Even more significantly, did the working-class populations we study operate within a liberal framework sufficiently enough to make liberal, state-centered concerns-the relationships and negotiations between actors in civil society (particularly articulated through unions and parties) and the liberal state-the "most potent tools" for political and historical analysis?

Katznelson's paper is admirable in many ways: in its sweep of many relevant literatures, in its incisive analysis of the theoretical tensions underlying the recent crisis in labor history, in its pugnacious insistence that labor historians not rest on their laurels, and in its openness about the author's own political commitments. In declaring himself out of the closet and proud to be a card-carrying liberal, Katznelson effectively moves us beyond the limits of the Marxist test for doing labor history, which too often has subjected historians and their subjects to an absurd kind of loyalty oath. Labor historians today as well as laboring men and women in history, it is frequently assumed, only operate within a narrow range of classconscious ideology and behavior. Although my own analyses of historical events in American history in fact have pointed to the persistent force of social class as identity and reality, I nonetheless reject any a priori assumption that working-class experience can always be understood as a function of class consciousness. Hence, I applaud the way Katznelson is opening up possibilities for historical analysis and loosening the noose labor historians have perhaps unintentionally hung around their own necks.

It is this appreciation for the way Katznelson has liberated labor historians from the necessity of subjecting their analyses to a political test that makes me suspicious of what he advocates replacing it with. Presumably, a truly liberal program for historical inquiry would fulfill Katznelson's own call for "intellectual variety" - a willingness "to embrace diversity in social analysis by way of a playful multidimensionality . . . [and] to rotate axes of

International Labor and Working-Class History

No. 46, Fall 1994, pp. 33-36

(C) 1994 International Labor and Working-Class History, Inc. 
inquiry without insisting on the decisive superiority of one's preferred approach"-and for a determination not "to insist that a state-centered agenda be competitive in a zero-sum way with other scholarly currents." When speaking of the tension often dividing postmodernists and more traditional historians, for example, Katznelson rightly insists that it is shortsighted to feel we must choose between "reality" and "signification." What I see at the heart of Katzelson's essay, however, is not an opening up of possibilities, but a too-rigid substitution of a new ideal of moral liberalism for a failed Marxist vision. Katznelson conflates-or confuses-a perfectly legitimate, personal, political choice to endorse the democratic potential of liberalism with the promoting of a new paradigm for historical analysis. While I applaud Katznelson's assertion that we must look at workers' participation in society beyond the narrow confines of their activities producing for a capitalist economy, I have doubts that his liberal statecentered approach is the all-inclusive solution he seems to think it is.

I am bothered on several fronts by Katznelson's solution to the "crisis of labor history." To begin with, I do not fully understand the relationship Katznelson is advocating between a state-centered approach and liberalism as a political ideology. Do the two in fact need to be linked? He argues, "To the extent that the state is important as an object of analysis for labor historians, it makes no sense to foreclose the critical use of the richest body of relevant theorizing currently being produced, even if it is flawed theorizing." But does the state not also play a role in nonliberal politics? Certainly, relations between the state and citizens were crucial in socialist countries as well. Working-class people's relationship to the state within liberal societies strikes me as a crucial topic for historical inquiry, but I do not see why liberalism need be endorsed to carry it out. "Working-class liberalism" is as compelling a subject for historicization as "working-class radicalism" or "working-class conservatism." But it is not at all clear how probing the attractions of liberalism for working people validates its authority as a contemporary political project.

Katznelson also seems unnecessarily to reject too much of what labor historians have achieved as they have moved beyond the limitations of the Commons School of labor economics and institutional analysis. A more expansive "working-class" history that examines workers in their families and communities, not just in workplaces, union halls, and voting booths; the complex way that culture mediates and transforms class politics and ideology; recognition of the intensely gendered and racialist nature of the labor story; the way that some poststructuralist tools of analysis have deepened understanding of workers' subjectivity; all have put labor history at the cutting edge of historical work over the last two decades. When Katznelson holds up as models for labor history the work of Henry Pelling, or even Theda Skocpol, despite their brilliance, I worry that we will lose touch with real working-class voices, real working-class culture, and issues within the lives of real working people that are not "state-centered." 
Moreover, labor historians over the last decade in fact have become more "state-centered" than Katznelson acknowledges, depending as he does on Goeff Eley and Keith Nield's 1980 assessment of the field as his straw man. Without returning to the narrow institutional frameworks of their forefathers, labor historians writing in recent years-Eileen Boris, Elizabeth Faue, Dana Frank, Gary Gerstle, Michael Kazin, Robin Kelley, Walter Licht, Marcus Rediker (and the list could go on)-have been concerned with politics and the state. What has made this work so important, however, has been the way historians have decentered politics and the state so that they are now understood as resulting as much from pushes from the bottom as from pulls from the top.

This brings me to a third concern. I am not convinced that Katznelson's new paradigm of examining state-civil society relations through the tenets of liberal political theory is always the appropriate analytical strategy, even for a politically ambitious labor history. It depends on the question the historian is asking and the era s/he is studying. The state can in fact be narrow as a terrain; perhaps it is power more broadly construed, not this one shape that power contestation can take within a society, that Katznelson really is advocating.

Let me elaborate through examples from my own work. Although I identify with the supposedly depoliticized "new labor history," my first book, Making a New Deal: Industrial Workers in Chicago, 1919-1939, was concerned with probing the interrelationship during the 1930s between industrial workers' cultural identities, their consciousness as workers and citizens, and their turn to two new institutions - the industrial union and the New Deal state. Here, a state-centered approach that probed the ways workers became increasingly invested in the structures of a liberal political order came naturally. How worker-citizens, on the one hand, and the policies and institutions of the New Deal state, on the other, both evolved through complex interaction became my subject. In this story, CIO unions, the local and national Democratic party, and government policies and agencies were ready vehicles for understanding the big questions for American labor during the 1930s.

For my current project, however, I am less sure that a state-society approach will direct me to the most significant arguments, and to impose it might lead to a distortion of reality. Certainly, there is a state-civil society story to be told for the post-World War II era, but my interest-as for most labor historians-is not to write a general history of those shifting relations. To focus on unions and political parties (as Katznelson has advocated) when both institutions have been in drastic decline, for example, would not likely reveal the crucial ways ordinary people have identified politically over the last fifty years. Rather, in A Consumer's Republic: The Politics of Consumption in Postwar America I am looking at how blue- and white-collar workers alike shifted their expectations for equality, freedom, and entitlements from state-centered institutions such as political parties 
and unions to more individualistic behavior such as consuming the promised fruits of the mass-consumption society. Certainly, state policies play an important role in this story. Highway building, the G.I. Bill, FHA and VA mortgages, tax laws, and credit rates and practices all contributed to creating a mass-consumption political economy and society that flourished between 1945 and 1970. Yet my point is that to assume that writing a more "political" labor history requires giving priority only to traditional political institutions could easily lead to missing the real story. Katznelson's liberal statist paradigm runs the risk of too narrowly defining politics and political behavior, in my view.

In conclusion, I would like to return to my earlier concerns about Katznelson's advocacy of a moral liberal politics in the context of trying to sort out a crisis in labor history. However understandable politically in this post-Soviet era, Katznelson's assumption of a necessary link between the current political environment and historical inquiry worries me because it runs the risk of confusing present conditions with past realities. Should the ambiguity surrounding social-class identity that has characterized postwar America, for example, color understanding of its previous significance? When Katznelson asks, "Why does class no longer seem to provide the best categories with which to describe the world? Why is the working class, in particular, so diminished as a historical actor?," he confuses observations of the contemporary world with the past. It may be that liberalism does not easily allow for a serious investigation of class as a category of analysis, but that only highlights the fallacy in his conflation of political philosophy with academic inquiry. To my mind, the lesson we should learn from the collapse of the anticapitalist world is not to replace Marxism with another doctrinaire set of answers, but rather to open things up and allow a broader range of possibilities, both in the kinds of historical analyses we undertake and the kinds of political alternatives we imagine. 